\title{
Tlingit Language
}

National Cancer Institute

\section{Source}

National Cancer Institute. Tlingit Language. NCI Thesaurus. Code C154170.

A Na-Dene language spoken by the T ling it people of Southeast Alaska and Western

Canada. 